\title{
Paper pulp waste-A new source of raw material for the synthesis of a porous ceramic composite
}

\author{
SUBRATA DASGUPTA* and SWAPAN KUMAR DAS \\ Central Glass and Ceramic Research Institute, Kolkata 700 032, India
}

MS received 12 June 2002; revised 30 August 2002

\begin{abstract}
A synthetic porous ceramic composite material consisting of the mullite, cordierite and cristobalite phases is produced from a mixture of paper pulp waste and clay by reaction sintering at $1400^{\circ} \mathrm{C}$. Physicomechanical properties such as bulk density, porosity, cold crushing strength and cold modulus of rupture have been studied. The presence of mullite, cordierite, cristobalite and quartz as major phases and montellecite, tatanite, forsterite and anorthite as minor phases have been confirmed by X-ray diffraction pattern. SEM studies revealed the presence of well developed needle shaped mullite and quartz crystals. The paper also discusses the possible uses of this type of porous composite material.
\end{abstract}

Keywords. Pulp waste; porous ceramic composite; mullite-cordierite-cristobalite.

\section{Introduction}

In general, wastes produced from pulp and paper industries belong to the group of organic wastes. They fall into two general classes with regard to their physical state, viz. suspended and dissolved. Most effluent pollution difficulties arising from this waste result from the discharge of fairly coarse suspended matter composed largely of fibre and other organic debris. A large portion of this settle at low stream velocities, causing the usual problems associated with organic waste deposits. $90 \%$ of the suspended matters are settable without the addition of coagulants. The common method of disposal is lagooning on earth embanked basins. In these basins, the sludge settles down and the supernatant water is siphoned off. The residue is allowed to dry to a degree where it can be transported to dumping ground. It is estimated that a paper mill having a capacity of $17 \mathrm{MT} /$ day paper production, generates an approximate $1.02 \mathrm{MT} /$ day of pulp waste. Safe disposal system or converting this waste into a useful material is the possible way for controlling the pollution caused by this waste material. Juvonen and Lehtonen (1994) used waste sludge from a paper plant to produce large ceramic pieces substituting a part of clay. Improved strength, fracture and bending properties were observed by them as compared to traditional clay bodies. Other researchers (Levesque and Accevedo 1994) also investigated the feasibility of producing porous, lighter terra cotta products with good compressive strength by introducing combustible organic materials into the clay

*Author for correspondence mass. Dasgupta et al (2000) conducted some basic studies on this material and observed that paper pulp waste contains $33 \%$ of ash, the chemical composition in wt.\% being 50-55 $\mathrm{SiO}_{2}, 28-35 \mathrm{Al}_{2} \mathrm{O}_{3}, 5-9 \cdot 5 \mathrm{MgO}, 1-2.5$ $\mathrm{CaO}$ and $1-3 \cdot 5 \mathrm{TiO}_{2}$. To utilize these important inorganic oxides of waste pulp, an attempt has been made in the present investigation to study its behaviour by reaction sintering with other alumino-silicate mineral such as clay. The physico-mechanical properties, viz. bulk density, porosity, cold crushing strength and cold modulus of rupture of sintered material are determined along with XRD and SEM studies.

\section{Experimental}

The chemical analysis of ash (obtained from the paper pulp waste) and clay are shown in table 1 . From various batch compositions (50-70 wt.\% paper pulp and 3050 wt.\% clay), optimum batch composition was selected (Dasgupta et al 2000). The mixture of pulp waste, clay and water was kept under ageing for around 3 weeks and stirred well with high speed stirrer before pot milling. The mixture was wet milled with water for a period of $10 \mathrm{~h}$ in the pot mill. The slip thus produced was sieved through 10 mesh B.S sieve and dried. After powdering the dried mass, rectangular samples of dimensions $100 \times$ $30 \times 30 \mathrm{~mm}$ were prepared at a pressure of around $170 \mathrm{~kg} / \mathrm{cm}^{2}$ by hydraulic compaction. The prepared samples were dried and heated at $1400^{\circ} \mathrm{C}$ in an electric furnace. The schedule of heating was maintained at RT to $250^{\circ} \mathrm{C}$ @ $1^{\circ} \mathrm{C} / \mathrm{min}$, at $250^{\circ} \mathrm{C}$, soaking for $1 \mathrm{~h}, 250-450^{\circ} \mathrm{C}$ @ $1^{\circ} \mathrm{C} / \mathrm{min}, 450$ to $600^{\circ} \mathrm{C} @ 0 \cdot 5^{\circ} \mathrm{C} / \mathrm{min}, 600$ to $1400^{\circ} \mathrm{C} @$ $2^{\circ} \mathrm{C} / \mathrm{min}$, at $1400^{\circ} \mathrm{C}$, soaking for $2 \mathrm{~h}$. The process flow 
chart for the preparation of the samples is shown in figure 1. The sintered samples were finally subjected to various physico-chemical tests such as bulk density, porosity, cold crushing strength and cold modulus of rupture by conventional testing methods. XRD study was carried out in X-ray diffractometer PW1710 (Anode-Cu, $40 \mathrm{kV}, 55 \mathrm{~mA}$ ). Microphotographs of the fractured surface of the sintered specimen were taken in Stereoscan Scanning Electron Microscope, LEO S430i.

\section{Results and discussion}

From table 1, it may be observed that the ash obtained from paper pulp contains considerable amount of $\mathrm{MgO}$. Presence of $\mathrm{MgO}$ is also found in the ashes of various air-dried vegetable materials, which have been used as a raw material for the preparation of ceramic glazes by many authors (Taylor and Bull 1986). Also it may be noted that the ratio of $\mathrm{SiO}_{2}$ and $\mathrm{Al}_{2} \mathrm{O}_{3}$ in the waste pulp is

Table 1. Chemical analysis of pulp ash and clay.

\begin{tabular}{lrr}
\hline $\begin{array}{l}\text { Major chemical } \\
\text { constituents (wt.\%) }\end{array}$ & $\begin{array}{c}\text { Ash of pulp } \\
\text { waste }\end{array}$ & Clay \\
\hline $\mathrm{SiO}_{2}$ & 51.70 & $56 \cdot 89$ \\
$\mathrm{Al}_{2} \mathrm{O}_{3}$ & 28.94 & 26.87 \\
$\mathrm{Fe}_{2} \mathrm{O}_{3}$ & 3.57 & 1.72 \\
$\mathrm{CaO}$ & 2.04 & 0.62 \\
$\mathrm{MgO}$ & 9.46 & 0.48 \\
$\mathrm{TiO}_{2}$ & 3.35 & 2.16 \\
$\mathrm{Na}_{2} \mathrm{O}$ & Trace & 0.34 \\
$\mathrm{~K}_{2} \mathrm{O}$ & Trace & 0.95 \\
L.O.I. & 0.85 & 9.75 \\
\hline
\end{tabular}

almost similar to the ratio that is commonly present in clayey materials. The compact samples prepared from the batch of pulp waste and clay on heating at $1400^{\circ} \mathrm{C}(2 \mathrm{~h}$ soaking) has given a reacted product having the physicochemical properties as shown in table 2 . From the results of table 2, it is evident that a light, highly porous, high strength material is obtained by heating pulp waste and clay at $1400^{\circ} \mathrm{C}$. The high CCS and MOR values are also supported by the observation of Juvonen and Lehtonen (1994) who produced a high strength porous ceramic body from a mixture of clay and fibre obtained from pure cellulose, recycled paper and waste sludge from a paper plant. In the present investigation pulp waste acted as a pore-forming agent in the composition due to its cellular structure. Such type of material containing significant amounts of $\mathrm{SiO}_{2}, \mathrm{Al}_{2} \mathrm{O}_{3}$ and $\mathrm{MgO}$ with pore forming capability is not very common from any single source. A highly porous ceramic body containing clay as a base material and sawdust as a pore forming agent has maximum crushing strength of $25-30 \mathrm{~kg} / \mathrm{cm}^{2}$ compared to as high as $135 \mathrm{~kg} / \mathrm{cm}^{2}$ in the present case. The XRD pattern (figure 2) shows the presence of mullite $\left(3 \mathrm{Al}_{2} \mathrm{O}_{3} \cdot 2 \mathrm{SiO}_{2}\right)$, cordierite $\left(2 \mathrm{MgO} \cdot 2 \mathrm{Al}_{2} \mathrm{O}_{3} \cdot 5 \mathrm{SiO}_{2}\right)$, quartz $\left(\mathrm{SiO}_{2}\right)$ and cristobalite $\left(\mathrm{SiO}_{2}\right)$ as major phases. Mullite, quartz and cristobalite are the commonly observed phases that are produced by sintering alumino-silicate type of mineral based compact mass (Schneider et al 1986; Carty and Senapati 1998). However, it is interesting to note from figure 2 that a considerable amount of cordierite is also formed which may be due to the presence of $\mathrm{MgO}$ in paper pulp waste. It is generally seen in the literature (Lamer 1949; Canost 1979; Achari et al 1988) that a separate source of $\mathrm{MgO}$ in the form of talc or $\mathrm{MgO}$ is used with alumino silicate materials and alumina to pro-

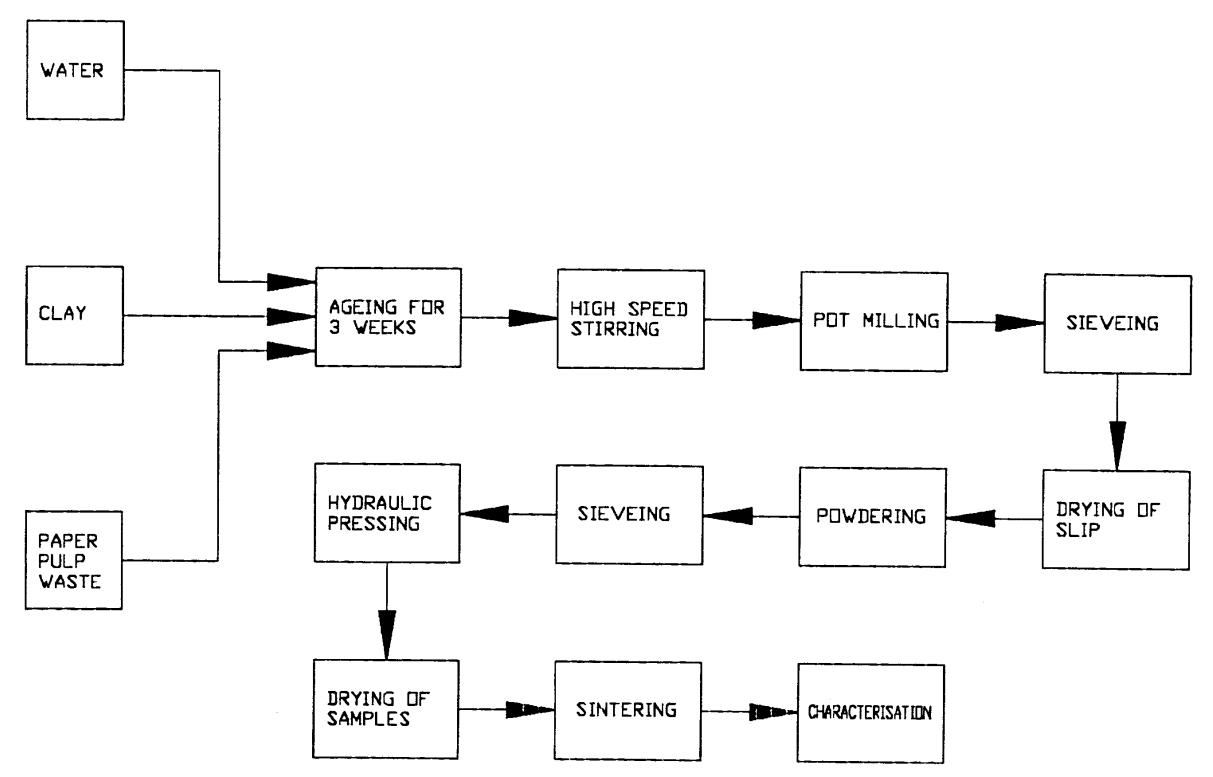

Figure 1. Process flow chart for sample preparation. 
duce cordierite and mullite phases. But, in the present study, pulp waste is a combined source of $\mathrm{SiO}_{2}, \mathrm{Al}_{2} \mathrm{O}_{3}$ and $\mathrm{MgO}$ which has given cordierite and mullite phases by reaction sintering with clay. It may also be observed from figure 2 that montellecite $\left(\mathrm{CaO} \cdot \mathrm{MgO} \cdot \mathrm{SiO}_{2}\right)$, tatanite $\left(\mathrm{CaO} \cdot \mathrm{TiO}_{2} \cdot \mathrm{SiO}_{2}\right)$, forsterite $\left(2 \mathrm{MgO} \cdot \mathrm{SiO}_{2}\right)$ and anorthite $\left(\mathrm{CaO} \cdot \mathrm{Al}_{2} \mathrm{O}_{3} \cdot 2 \mathrm{SiO}_{2}\right)$ are also present as minor phases in the heated sample. Presence of $\mathrm{CaO}, \mathrm{MgO}$ and $\mathrm{TiO}_{2}$ in paper pulp might have contributed towards the development of these minor phases. The SEM photographs taken on the fractured surface of the different portions of the sintered specimen are shown in figures $3 a-b$.

Table 2. Physico-chemical properties of the sintered sample.

\begin{tabular}{lr}
\hline Properties & Value \\
\hline Chemical analysis (wt.\%) & \\
$\mathrm{SiO}_{2}$ & $55 \cdot 99$ \\
$\mathrm{Al}_{2} \mathrm{O}_{3}$ & $36 \cdot 37$ \\
$\mathrm{Fe}_{2} \mathrm{O}_{3}$ & $1 \cdot 50$ \\
$\mathrm{CaO}$ & $1 \cdot 13$ \\
$\mathrm{MgO}$ & $3 \cdot 04$ \\
$\mathrm{TiO}$ & $1 \cdot 23$ \\
$\mathrm{L.O} . \mathrm{I}$. & $0 \cdot 72$ \\
$\mathrm{Bulk}$ density (g/cc) & $1 \cdot 36$ \\
$\mathrm{Apparent}$ porosity (\%) & $50 \cdot 04$ \\
$\mathrm{Cold}$ crushing strength (kg/cm $\left.{ }^{2}\right)$ & $135 \cdot 64$ \\
$\mathrm{Cold}$ modulus of rupture (kg/cm $\left.{ }^{2}\right)$ & $41 \cdot 00$ \\
Thermal shock resistance (Heating & Withstood 20 \\
at $1000^{\circ} \mathrm{C}$ and quenching in air) & cycles \\
\hline
\end{tabular}

Presence of well developed needle shaped mullite and quartz crystals are seen in these microphotographs. Quartz crystals are also clearly seen in figure 3a. A crack is observed in figure $3 \mathrm{a}$ which might have generated during fracturing of the sample prepared for SEM analysis. The morphology of such composite materials stops lamination and helps easier pressing of ceramic bodies as observed by Kumar (1994) also. The matrix embedded with needle shaped mullite crystals contributed towards development of higher crushing strength and cold modulus of rupture in spite of higher porosity and low density. It is known that mullite and cordierite possess lower coefficient of thermal expansion (Hummel 1984; Schneider et al 1994). The presence of such low expansive synthetic phases and large amount of pores improves the thermal shock resistance of the material significantly. The matrix embedded with needle shaped mullite crystals also help to resist the formation or propagation of cracks caused by thermal stress induced by large temperature difference during its application.

The light weight, porous and high strength composite materials produced in the present study may find potential applications as heat insulating refractory material for furnace lining in the temperature range of $1200-1300^{\circ} \mathrm{C}$. It has been reported in the literature (Chen et al 1998, 1999) that cordierite and mullite are commonly used materials for kiln furniture. The present investigation succeeded in synthesizing a strong porous mullitecordierite composite material which may be suitable for kiln furniture applications in the temperature range of $1200-1300^{\circ} \mathrm{C}$. This material in the aggregate form after

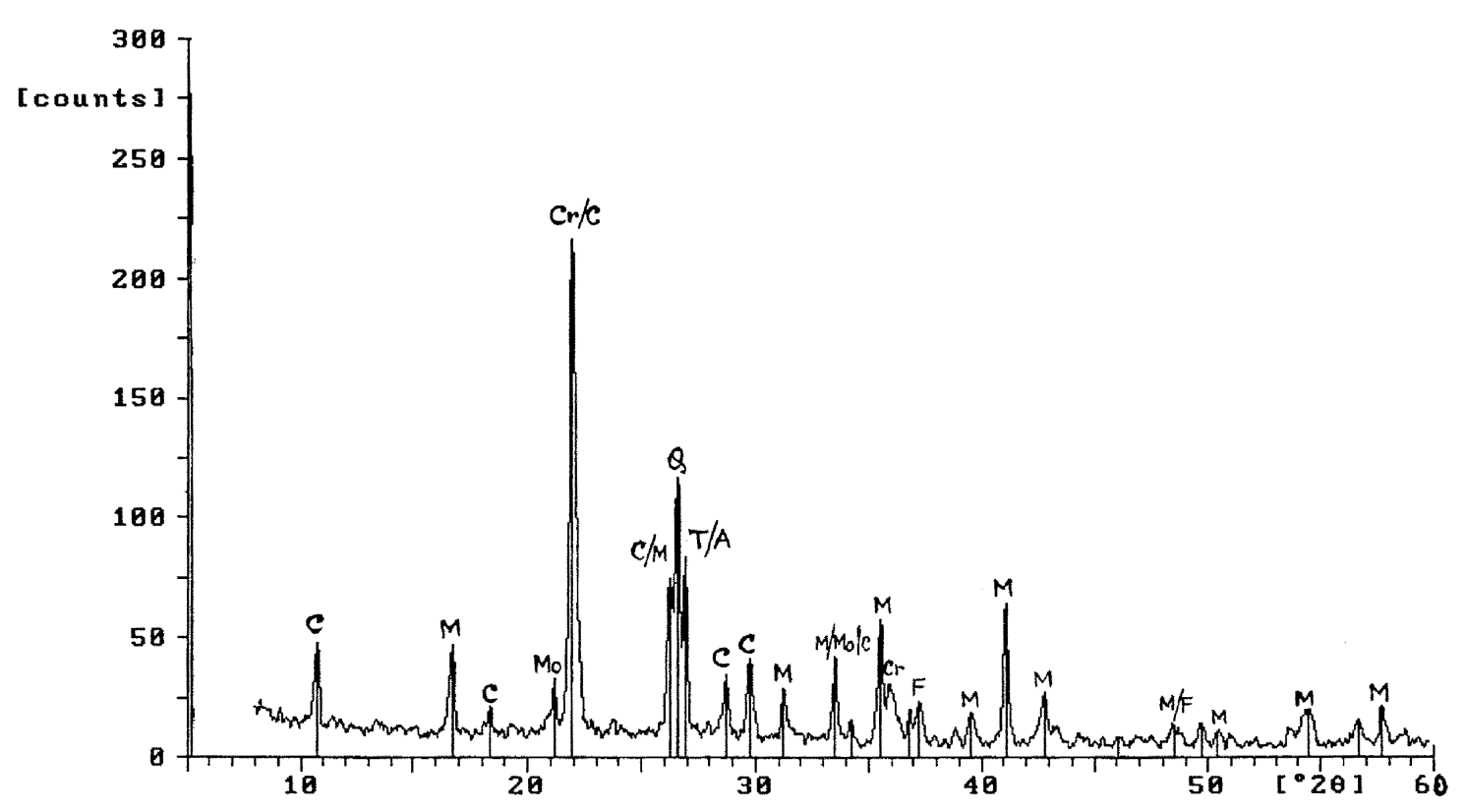

Figure 2. $\mathrm{XRD}$ pattern of the specimen sintered at $1400^{\circ} \mathrm{C}(\mathrm{Q}=\mathrm{Quartz}, \mathrm{M}=$ mullite, $\mathrm{C}=$ cordierite, $\mathrm{Cr}=$ cristobalite, $\mathrm{Mo}=$ montellecite, $\mathrm{T}=$ tatanite, $\mathrm{F}=$ forsterite, $\mathrm{A}=$ anorthite). 

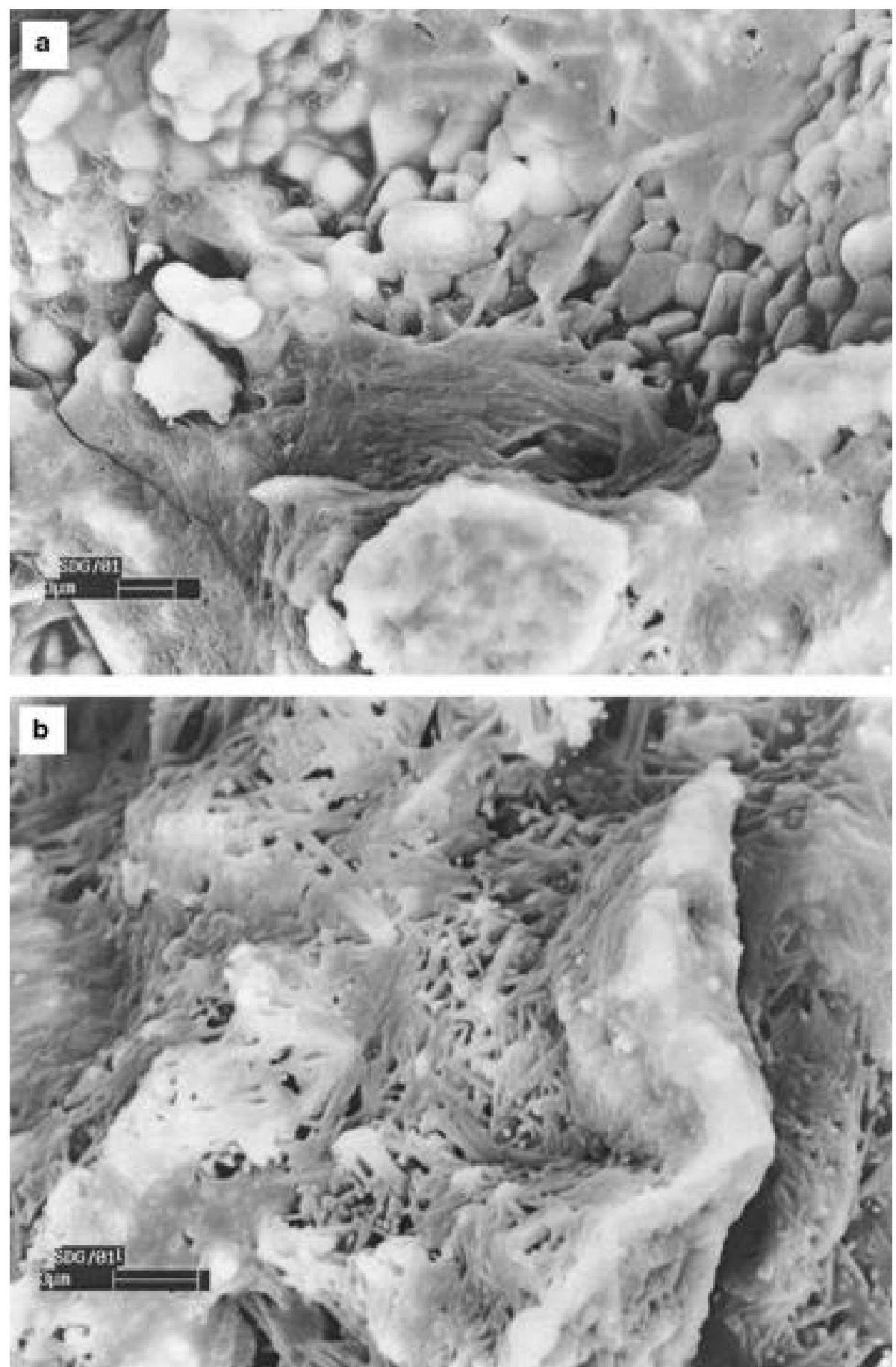

Figures 3. a-b. SEM photomicrographs of the sintered specimen taken on the fractured surface.

crushing and grinding into different size fractions may also find applications in refractory castable as insulating aggregate.

\section{Conclusions}

From the present study, the following conclusions are drawn:
(I) Reaction sintering of waste paper pulp and clay produces a porous ceramic composite material consisting mainly of mullite, cordierite and cristobalite phases as confirmed by XRD studies.

(II) The light weight highly porous material developed in this study possesses high crushing and flexural strength compared to other lightweight ceramic product of similar kind. 
(III) The matrix embedded with needle shaped mullite crystals as confirmed by SEM studies may resist the formation and propagation of cracks caused by thermal stresses induced by a large difference during its application as heat insulating and thermal shock resistant material.

(IV) The present study utilizes a solid waste of paper pulp industries thus minimizing the environmental pollution.

\section{Acknowledgement}

The authors wish to thank Prayas Paper Mill, Kolkata, for supplying the paper pulp waste.

\section{References}

Achari S A, Sampathkumar N N and Das S K 1988 Interceram 125

Canost S 1979 Interceram 161
Carty M W and Senapati U 1998 J. Am. Ceram. Soc. 813

Chen Z et al 1998 Paper presented at the 3rd international symposium on refractories, Bejing, China

Chen Z, Myhre B, Odegard C, Hundere A M and Sandberg B 1999 Paper presented at the 101th annual meeting of Am. Ceram. Soc., Indianapolis, Indiana

Dasgupta S 2000 Indian Patent No. 1055/DEL

Dasgupta S, Das S K, Banerjee G, Dhar N N, Mondal P K and Mukherjee S 2000 Indian Patent No. 1202/DEL

Hummel F A 1984 Interceram 3327

Juvonen L and Lehtonen A 1994 Paper presented at the 8th CIMTEC World Ceramic Congress, Florence, Italy

Kumar S 1994 Handbook of ceramics (Kolkata: Kumar \& Associates) Vol. I

Lamer R S 1949 J. Am. Ceram. Soc. 3265

Levesque R and Accevedo J 1994 Paper presented at the 8th CIMTEC World Ceramic Congress, Florence, Italy

Schneider H, Majdic A and Vasudevan R 1986 Mater. Sci. Forum 791

Schneider H, Okada K and Pask J A 1994 Mullite and mullite ceramics (Chichester, UK: John Wiley and Sons Ltd.) p. 199

Taylor J R and Bull A C 1986 Ceramics_glaze technology (Oxford, NY: Pergamon Press) p. 136 